\title{
Early detection of extremism? The local security professional on assessment of potential threats posed by youth
}

\author{
Annemarie van de Weert $^{1}$ (D) - Quirine A.M. Eijkman ${ }^{1}$
}

Published online: 10 December 2019

(C) The Author(s) 2019

\begin{abstract}
Frontline professionals such as social workers and civil servants play a crucial role in countering violent extremism. Because of their direct contact with society, firstliners are tasked with detecting individuals that may threaten national security and the democratic rule of law. Preliminary screening takes place during the pre-crime phase. However, without clear evidence or concrete indicators of unlawful action or physical violence, it is challenging to determine when someone poses a threat. There are no set patterns that can be used to identify cognitive radicalization processes that will result in violent extremism. Furthermore, prevention targets ideas and ideologies with no clear framework for assessing terrorism-risk. This article examines how civil servants responsible for public order, security and safety deal with their mandate to engage in early detection, and discusses the side effects that accompany this practice. Based on openinterviews with fifteen local security professionals in the Netherlands, we focus here on the risk assessments made by these professionals. To understand their performance, we used the following two research questions: First, what criteria do local security professionals use to determine whether or not someone forms a potential risk? Second, how do local security professionals substantiate their assessments of the radicalization processes that will develop into violent extremism? We conclude that such initial risk weightings rely strongly on 'gut feelings' or intuition. We conclude that this subjectivity may lead to prejudice and/or administrative arbitrariness in relation to preliminary risk assessment of particular youth.
\end{abstract}

Annemarie van de Weert, MSc, is a researcher of local anti-extremism policy at the Research Centre for Social Innovation at the University of Applied Sciences Utrecht. Dr. Quirine Eijkman is Deputy President of the Netherlands Institute for Human Rights and is professor Access2Justice at the University of Applied Sciences Utrecht. This article is written in her personal capacity. Research Group Access2Justice

Annemarie van de Weert

annemarie.vandeweert@hu.nl

Extended author information available on the last page of the article 


\section{Introduction}

The policy of countering violent extremism (CVE) is a non-coercive attempt to reduce involvement in terrorism by focusing on collecting information about 'potentially threatening individuals'. Currently, this approach forms the basis of the European policy in this field and thereby, suggests there is anticipation of a future threat of terrorist violence. The assumption that anyone who has committed a terrorist offense has undergone a prior process of radicalization forms the basis of CVE-policy $[1,2]$. Because of this broad approach, municipalities and frontline professionals ${ }^{1}$ (such as youth workers, civil servants responsible for public order and safety, and community police officers) find themselves placed at the intersection of providing social care and guaranteeing community security. They face a dual task: to care for the health and wellbeing of inhabitants while simultaneously being expected to report any information that might be relevant from an intelligence and security perspective - a perspective that focuses on external threats such as extremist violence and terrorism [4-6].

This counterterrorism practice integrates a preventive strategy, focused on early detection of radicalization before a willingness to commit violence is present, with a criminal law (repressive) strategy [7]. This strategy calls for an integral, cross-sector approach and the involvement of different governance levels in the CVE-policy. However, in this phase, prevention is concerned mostly with the symbolic arena, as indications of radicalization are sought in expressions or deviant attitudes. Because the assessment of indicators takes place during the pre-crime phase- a moment when no concrete unlawful activity has occurred, and which instead interprets ideas and ideologies as signs of risk - it can be said that municipalities and healthcare and welfare professionals have become agents of social control [8].

As of yet, little is known about the effect of CVE-approaches because, in many countries, the success of the implementation of these policies has not been evaluated [7, 9-12]. It is important to note that the practice of counterterrorism depends also on political considerations - such as 'we have to do something' - rather than on only evidence-based practice [13]. It is, thus, unsurprising that there is a lack of clarity regarding whether the organisations involved in CVE-policy are able to provide their services with sufficient quality. Given the lack of insight into the policy's effects, our assumption is that we must begin by studying the very basics, by mapping the activities of those frontline professions that give effect to early detection at the local level. This vision gave rise to this study on screening at a pre-emptive stage, which takes place prior to punishability.

\section{Literature review}

The recent wave of terrorist attacks in Europe has made counterterrorism a concern among local governments. Because municipalities and frontline professionals have direct contact with society, they play an important role in detecting, as soon as possible,

\footnotetext{
1 'In all cases, frontline professionals are executive officers whose every-day work is characterised by high levels of contact with inhabitants, a certain measure of discretion, and continuous work pressure, because there is an almost unlimited demand for the particular public service' ([3], p. 11).
} 
potentially threatening individuals and the risk these individuals pose to democracy. Social and political demands for speedy measures mean that frontline professionals have had to adjust to a quickly changing political reality. In essence, priority is given to sharing information so as to improve the intelligence position of professionals within the security sector. Therefore the local CVE-policy seems to entail mainly an early detection system at the local level, with little attention paid to other means of preventing radicalization [1]. If it is the case that the municipality has become an extension of the intelligence and security services, we are, in fact, asking local frontline professionals to be informants for the security apparatus [14]. In this way, early detection can be seen as a repressive approach instead of a preventive measure [2].

When a front-line professional operates preventively in the area between social welfare and early-detection of violent extremism, his/her judgment is particularly unstructured and not entirely objective. Such was the outcome of the few studies about early detection that have been conducted among front-line practitioners so far (e.g., Aly, Balbi \& Jacques [15]; [16-19]). This outcome seemed to stem from a lack in the necessary development of knowledge that has taken place among local security experts, in the inconsistent use of concepts such as radicalization and (violent) extremism, and in doubts about the ability to accurately assess potential risk at such a level.

When discussing risk assessment, it is also important to realise that people evaluate risk from their own perspectives [20]. Moreover, professionals are highly attuned to information that confirms their ideas and-regardless of how competent they areinterpret new information to confirm their own assumptions [21-24]. This reflex is known as 'confirmation bias' - the preference for confirming existing beliefs. People exhibit this bias when they gather information selectively or when they interpret information in a subjective manner. Such a practice increases the risk of so-called 'false positives' (i.e., people who are identified as potentially risky when, in all likelihood, they would never engage in violence). Vice versa, there is a risk of 'false negatives' (i.e., people who are not considered dangerous and who eventually do engage in violence). Both outcomes have negative implications.

Considering the concept of 'performativity' [25], which points to a distinct relationship between the performative power of counter-terrorism instruments and the effectiveness of the local approach, we argue that the overall effect of the policy in question is not necessarily determined by the policy measures and their intended results as such, but much more by the way in which they are presented and perceived. This means we should focus more on the actual practice on the ground. Based on the literature, there is also significant substation to delve into practical realities. For example, it is not easy to capture in words, laws, and methods how one is to recognise and assess signs of radicalization processes [26-28]. The professional must be on the lookout for the first signs of deviant attitude; however, no clear framework is provided for such a preliminary judgment - if it is even possible to set up. Thus, we can be almost certain that the assessment of potential risk and radicalization processes in a very early stage does not take place methodologically. This is even more the case with regard to potential threats posed by ideologies in the so-called pre-crime phase. In the end, no one - not even terrorism experts - can say for sure when someone actually poses a threat, until the point at which the individual engages in concrete activities [29]. Early detection and investigation are, therefore, based mainly on estimations and personal moral judgement [19]. 
Critics of counterterrorism policy believe that the lack of concrete metrics for detection and assessment within the securitised local approach negatively affects the effectiveness of the policy [30-34]. This concern is based on the fact that subjectivity in judgment can lead to increased levels of stigmatisation and discriminatory profiling, as well as the fact that the act of being labelled a security risk can be experienced as unjust. Such feelings of injustice are an important breeding ground for extremism [30, $35,36]$. Furthermore, it is important to realise that radicalization and extremism, in themselves, are not criminalised. It is only when these processes lead to violent intentions, the incitement of violence and hatred, or violence itself that we can speak of a criminal act. It is, therefore, the process of radicalization towards violent extremism that should be addressed and not radicalism or extreme behavior in general. Borum [37] refers to this as "the processes by which people come to adopt beliefs that not only justify violence but compel it, and how they progress—or not—-from thinking to action".

However, when professionals determine how potentially threatening attitudes might become terrorism-related behavior, their decisions are often based upon radical beliefs (e.g., made by the youth in question) and, as such, have implications for the right to freedom of expression. It is, therefore, of great importance to map the ways in which someone is deemed as posing a possible threat to national security and/or the democratic rule of law and which criteria are used in this assessment [38]. The lack of a clear legal framework for assessing an individual's mindset can lead to inadequate risk assessment. Social justice should, therefore, be addressed at the level at which it occurs. This is because, in most cases, (local) actors such as national governments, municipalities, courts, and police at the front line bear responsibility for the daily implementation of the rule of law.

Lastly, the way in which municipalities define the risks of extremism is linked to the effectiveness of their counterterrorism policy. In other words, to assess the social effects of the local approach to violent extremism, we wonder: What exactly do frontline professionals consider a potential risk to democracy to be? How is violent extremism assessed based on that framework? And, do frontline professionals have the necessary knowledge and understanding to assess whether someone is prepared to use violence? Clarity is needed in terms of how these different concepts are perceived in the municipalities tasked with implementing counterterrorism policy. By gaining knowledge of the perspectives that the coordinating security civil servant takes during the initial assessment stages and the ensuing decision-making processes, we take a first step towards being able to reflect upon the practice of countering violent extremism policy implementation at the local level.

\section{Methods \& analytical Strategy}

The present article reviews the scope of the early detection of potentially threatening individuals. The assumption is that prevention at the local level is the most effective measure against terrorism. To effectuate early detection, multidisciplinary regional networks have been created. Frontline professionals such as community police officers, security coordinators, youth workers, social workers, and even teachers play a key role in detecting violent extremism. The task facing local frontline professions in the 
Netherlands, in practice, is to 'identify when a person is radicalising in a manner that potentially forms a threat to national security and the democratic rule of law'. The realisation of this task demands much from the frontline professionals working in the overlapping domains of security, safety, welfare, and healthcare. To fulfil their role, frontline professionals must reach a consensus on, and achieve clarification of, the exact form of extremism that is to be prevented. Furthermore, the article focusses on the local approach to counter violent extremism among teenagers and young adults (until about twenty-three years of age). We refer here particularly to the municipality's comparable role under the Dutch Approach to Youth Crime, which states that 'the frontline fulfil[s] both an early-detection function and a referral function toward youth services.'

Because the broad approach to counterterrorism employed in the Netherlands is often cited as a universal example of CVE-policy [1], we used Dutch professionals as the case study for this article. Fifteen municipalities participated in this exploratory study. These municipalities were selected from the list of priority regions that received funds for the targeted prevention of radicalization and the strengthening of multidisciplinary networks. ${ }^{2}$ The respondents were all civil servants in the department of Public Order \& Safety (Openbare Orde \& Veiligheid). This department is closely linked to the police and justice sector with regard to the investigation and prosecution of crimes. Of the twenty municipalities we approached, fifteen civil servants responsible for counterterrorism policy were willing to be interviewed. These were the most senior employees in their role. All were head of a team responsible for the 'radicalization' portfolio within the department of Public Order \& Safety. The gender of all the respondents was male. They were all aged above 30 when interviewed. Education varied from studies in integral safety science to engineering or social sciences. However, in this study, we do not consider these characteristics to be relevant to the outcome of the analysis. This is all the more so because our scope did not include testing the professionalism of the professionals and the influence of their background on the same; rather, it was to gain insight into their ideas about fulfilling their role in general. The respondents all consented to having the conversations recorded, under the condition that all statements would be anonymised. The interviews were conducted one-on-one during the period between August 2017 and the end of February 2018. Each interview lasted about one-and-a-half hours and was 'open' in the sense that it did not follow a pre-set structure.

To discourage answers that were too general, superficial, or politically correct, we asked the respondents to clarify and expand on their answers during the interview (probing). The use of probing in open interviews has the advantage of allowing the researcher to gain insight into the respondents' perceptions, experiences, and opinions in relation to complex and sensitive subjects [39, 40]. Rubin and Rubin [40] call the use of probing in open interviews 'responsive interviewing'. This technique maintains many similarities to journalistic questioning. It can also be seen as a method that generates story-telling interviews, because the interviewee is encouraged to tell his/her

\footnotetext{
${ }^{2}$ As described in the February 2015 letter to the Dutch Parliament, 'Versterking van de Veiligheidsketen' ('Strengthening the Security Chain'), since 2015 the Dutch government has made funds available for a multiple-year enhancement of the local approach towards radicalism in the period from 2016 until the end of 2020. https:/www.nctv.nl/actueel/nieuws/2017/geld-naar-gemeenten-voor-lokale-aanpak-radicalisering-enjihadisme.aspx. Accessed 15 April 2018.
} 
story. Such interviews are also referred to as narrative interviews [41]. These methods encouraged the respondents to expand on the following themes: extremism, threats, prevention, multidisciplinary cooperation, security, risks, and assessment of data.

Following the work of Durose $[42,43]$ with respect to frontline work, we situate this study within the body of interpretive work in public policy. All the outcomes of conversations were analysed using the 'constant comparative method'. This method adheres to principles comparable to those in thematic analysis, whereby specific subjects are schematically distilled from the text. However, the constant comparative method focuses more on describing variation, which gives us the possibility of recognising systematic differences. This allows one to identify meaningful patterns in, and relationships between, empirical data [44]. The constant comparative method is, thus, preferable in cases in which the aim is to discover perceptions of important concepts. The present study uses this method to filter the concepts of radicalization, (violent) extremism, risk assessment, and threats to democracy out of the various stories that the interviewees told. This allows us to describe how the process of early detection works in practice in different municipalities as well as to describe professionals' personal experiences with these processes.

Finally, despite the need to obtain insight into the effectiveness of policy (especially when it comes to complex problems such as counterterrorism in which wrongdoing has consequences), it remains difficult to achieve unconditional collaboration to map local practice. This is due primarily to a feeling of uncertainty about one's own actions and a feeling of being controlled. In addition, lack of time plays a role. We are aware that the number of respondents (15) may seem low. Nonetheless, this is a quite high number compared to the numbers in other studies focusing on the perspectives of local practitioners in CVE. For example, Mattsson [17] interviewed 13 informants. Additionally, Peddell et al. [18] reached a number of five because of an 'opportunity sample'. Also, while the use of narrative analysis has clear advantages, it remains a complex, ambiguous, selective, and subjective method [45], which means the conclusions of this article must be viewed as a starting point for further research.

\section{Results: perceptions of local security professionals}

To understand the possible side-effects of the local approach towards (violent) extremism, we must study how local civil servants responsible for Public Order \& Safety engage in the early detection of extremist expressions among youth. To obtain a picture of this practice, we use the following two research questions to reflect on the results of our interviews with local security professionals: Firstly, which criteria do local security professionals use to determine whether or not someone constitutes a potential risk? Secondly, how do local security professionals substantiate their assessments of radicalization processes developing into violent extremism?

\section{Potential risk?}

The Dutch Ministry of Justice and Security defines radicalization as related to the broad spectrum of radical ideology that poses a threat to the democratic rule of law and 
the safety of citizens. ${ }^{3}$ Because this definition is relevant for the early-detection task set for municipalities, we asked the fifteen security civil servants who participated in the current study about this statement. How do they know when a person is radicalizing in a way that potentially poses a threat to national security and the democratic rule of law?

When interviewees responded to the question 'When is someone a threat to society?', they almost immediately began to list actions that could be classified as unlawful, such as the intention to leave the country to participate in terrorist activity, recruiting for terrorism, or preparing an attack or incidence of physical violence. That makes sense, because these are indicators of a threat for which concrete evidence can often be found. Moreover, these actions are ones that the national government in the Netherlands first used administrative measures to target (by revoking passports or banning individuals from certain areas, as was done in 2017 to a Salafist imam). The responsibility for implementing some of these laws, such as the Temporary Law on Administrative Measures for Counterterrorism, ${ }^{4}$ lies with the mayor of the municipality. Most municipalities in which we conducted interviews had experienced cases that fit within a particular legal framework. The interviewees also spoke of famous cases that had received media attention for their use of criminal law to prosecute threats. It is not surprising that most of the civil servants for public order and security who participated in this study focused on detecting potentially criminal behaviour; this is, after all, what they are familiar with.

However, when we asked the interviewees about the 'ideology' or 'ideas' that potentially form a threat, the explanation about how a threat can be identified came to a halt. Here, the interviewees replied that the indicators of such potentially threatening ideologies or ideas are abstract and do not rely on concrete actions. As respondent number five explained, 'If you only have a signal about someone's attitude [for example, in the classroom, author's addition], this is difficult to classify as innocent or not. Where is the line?' A number of respondents (one, two, four, eight, and ten) provided examples of signals they received relating to 'harsh' or 'hostile' language. They took these signals into account in their assessment in order to avoid any risk of missing important signals. Respondent number four provided a further explanation: 'You receive a report on a youth who showed "aggressive behaviour" in his language use.' What exactly 'aggressive' means in this context, the security officer could not clarify. His only answer was: 'That is difficult because youth say so much nowadays. I think they themselves often don't even know what they mean.'

When we probed the respondents further about ideas and expressions that could form a threat to society, almost all the respondents provided examples of cases that the 'weighing team' had discussed. After we explicitly asked the respondents, it became clear that most of these examples did not involve verbal threats of violence. Verbal threats of violence occur when language is used to incite hate, intolerance, or antidemocratic behaviour or seeks to limit the freedom of others. ${ }^{5}$ The law specifies that such

\footnotetext{
${ }^{3}$ See 'Mededeling over ondersteuning ter voorkoming van radicalisering die tot gewelddadig extremisme leidt' ('Notice on Support for Preventing Radicalization that Leads to Violent Extremism') Number Commission document COM (2016, p. 3) 379.

${ }^{4}$ Tijdelijke wet bestuurlijke maatregelen terrorismebestrijding (Temporary Law on Administrative Measures for Counterterrorism) (Explanatory Memorandum Parliamentary Papers 34,359, number 3).

${ }^{5}$ See 'Mededeling over ondersteuning ter voorkoming van radicalisering die tot gewelddadig extremisme leidt' ('Notice on Support for Preventing Radicalization that Leads to Violent Extremism') Number Commission document COM (2016, p. 3) 379.
} 
language can be qualified as an unlawful call to violent action, such as an incitement to hate or discrimination. The respondents' examples, however, related generally to verbal expressions that could be considered criticism of another or another's group or to expressions that were otherwise disturbing. Respondent number two provided the example of a group of boys who had said that God would punish homosexuals because they are dirty people. A number of respondents cited, as an example of a hostile attitude, the justifying of attacks on Westerners (respondents number three, five, seven, nine, and fifteen).

After the interviewees reflected on these responses, about one-third of them realised that the ideology-based cases they had provided as examples were actually not instances of incitement to violence, hate, or intolerance. They seemed to become (or be) aware of the fact that most cases dealt with those who, while engaging in hostile discourse, likely did not have any intention to actually engage in violence. Most respondents experienced this realization as a (significant) dilemma (respondents three, four, five, six, seven, eight, nine, ten, eleven, thirteen, fourteen, and fifteen). They asked themselves whether the hostile language they observed was always necessarily a threat to the security of others. In other words, when does aggressive speech or an aggressive attitude also involve the intention or willingness to use violence? What is the actual risk to democracy?

Upon reflection, a number of these local security officials implied that they understood that their interpretation of early detection policy might conflict with human and/ or constitutional rights, such as the right to freedom of expression (respondents one, four, five, six, ten, eleven, fourteen, and fifteen). However, their impressions seemed to be based more on common sense (also called 'folk wisdom', [46]) than on an actual understanding of the content of fundamental rights. The following answer, given by respondent one, illustrates this perspective: 'Everyone has the right to their opinion, of course. You are allowed to think what you want in the Netherlands.' Such responses seem to indicate that, among local civil servants responsible for security, legal knowledge about the freedom of expression is incomplete. As mentioned earlier, human rights law gives individuals significant freedom to make their opinions known without any interference from the State. This freedom is, however, not absolute. When an individual engages in hate speech or an explicit incitement to violence, the government may intervene. In the Netherlands, for example, incitement to hate and violence is criminalised under Article $137 \mathrm{~d}$ of the Dutch Criminal Code.

While we acknowledge that detecting and understanding nuanced behavioral changes that signify a dangerous turn towards radicalization to violence may not always be easy, it is important for the local security professional to understand the importance of detecting an individual's willingness to commit or incite violence. For this, the local security professional needs some knowledge of legal norms, so as to be able to conduct his/her assessment within a framework of fundamental norms such as freedom, equality, and solidarity. Yet, none of the respondents mentioned, of their own accord, the signs that can indicate an intention to use extremist violence. Respondent number five came closest when stating the following: 'What matters is, of course, what someone means with their statement.'

The inability to assess the difference between, on the one hand, incitement to violence and hate and, on the other hand, intolerant statements which could possibly — but not necessarily — be related to a willingness to use extremist violence 
reveals a legal blind spot among local security professionals. This is particularly concerning because security professionals seem to focus on the use of aggressive language by a specific group (Muslim youth), while dismissing the same or similar language as youthful brashness when it is used by other groups. Islamic extremism is still a leading concern of local CVE policy. We must bear in mind that this can lead to stigmatisation, discrimination, and unjustified profiling. In such cases, we can say that the rule of law does not always treat similar cases equally and that this undermines the principle of equality upon which democracy is based. Our conclusion is that a sufficient understanding of the norms underlying human rights, citizenship rights, and tolerance is not consistently present in local counterterrorism policy.

\section{From radicalization towards violent extremism?}

In this study, we focus solely on the radicalization processes that lead to violent extremism. In Dutch communities, the distinction between radicalization and violent extremism is often not clearly made. Furthermore, in most policy documents, radicalization is referred to only in the context of early detection. The political discourse often misses a clear focus on violence as that which must be prevented. To assess whether someone's ideology or ideas do, in fact, pose a threat, we must ascertain whether there exists an intention to use or incite violence. We must thus be able to distinguish between radicalism and extremism as ways of thinking, versus the acceptance of violent behaviour. We start from the assumption that this distinction is often difficult to make based on the indicators for risk that are available to local security professionals. These indicators generally consist of observable changes in behaviour and appearance $[28,47]$. In what follows, we map out how local security professionals substantiate their findings on radicalization and violent extremism within this ambiguous field.

During the interviews, we learned that a large majority (ten of the fifteen respondents) look for behavioural changes among youths when trying to assess abstract indicators such as ideology or ideas. Such changes can be precursors to extremism. The local security professionals indicated that they paid particular attention to whether the youth had recently been involved in incidents such as dropping out of school, coming into contact with the police, getting into fights with peers, causing a nuisance in the neighbourhood, or experiencing family problems. To investigate whether such incidents had occurred, the professionals collected information from different municipal network partners by asking whether the partner knew of a particular individual. As respondent eight described it, 'You kind of do a check of the plusses and minuses.' He said he meant this literally: "The social authorities give the person a "plus" if they think that the reason the youth is known to them could lead to concerns about radicalization. The more plusses on the list, the bigger the risk someone poses.'

Although all fifteen interviewed civil servants responsible for security, safety, and public order at the local level indicated that they had taken a course or received training to improve their detection of radicalization, this should not be interpreted to mean that they are capable of fully identifying particular ideologies. A number of respondents confirmed as much (respondents one, four, five, six, eight, and fourteen). The following reaction from respondent fourteen shows how elusive ideology can be: 'You can try to understand it, but that does not mean you will succeed.' Moreover, many of the courses and trainings that these local security professionals received are offered by commercial 
parties and are subject to little oversight. This means that it is not clear whether-and, if so, how-these non-governmental experts and the content of the course are evaluated [7]. Our interviews with local security professionals did reveal that all such trainings have, so far, one-sidedly focused on detecting religious (Islamic) extremism or Jihadism. This was clear from the indicators that the interviewees repeatedly mentioned: change of appearance (wearing a kaftan or djellaba or growing a beard), resistance towards Western authorities, intolerant behaviour at school and towards women, learning Arabic, changed eating habits (halal and haram), etc. Detecting other types of ideologies (such as left-wing and right-wing extremism and the sometimesextreme ideas of environmental and animal rights activists) is insufficiently attended to in these courses.

In evaluating the assessment process, we noted that little to no attention is paid to the possibility that behavioural change could indicate the natural age-related process of identity development. While the phenomenon of an 'identity crisis' is sometimes referenced, it is not clearly explained how one should assess the 'radicalization stage' of the youth involved undergoing such an identity crisis, or which part 'ideology developments' play. It would be important to know how to recognise particular stages in the process of ideological change, as well as whether someone has an open or closed mind regarding democratic core values such as freedom, solidarity, and equality (see for an overview [48]). The interviewed local security professionals, however, seemed to not be mindful of the fact that extremism is often linked to a mind that is closed to other views - a characteristic that makes one intolerant. This fits with the overall observation that these frontline workers have difficulty making the terms, phenomena, and concepts they work with explicit, which forces them to rely heavily on assumptions.

In the end, all respondents admitted, rather explicitly, that their risk assessment is based on intuition. This shows parallels to the answers to question (1) regarding the criteria that local security professionals use to determine whether someone represents a potential risk, as set out in the previous section. There, we saw the extent to which one's 'gut feeling' is relied upon in deciding whether an individual represents a potential threat. Upon reflection, it appeared that most local professionals rely on the importance of finding the 'best person to do the job' instead of on looking for 'best practices' to fulfill their specific assignment in early detection. Although this is a realistic view of early detection practice (as this practice is not evidence-based), the lack of checks on their judgements and decision-making means that cognitive bias could be influencing their assessments. Current scholarship on the influence of cognitive bias on risk assessment shows that biases such as authority bias and overestimating one's own ability often lead to significant under- or overestimation of security threats. The risk assessment of extremism among youth is, thus, vulnerable to errors in judgment. After all, when assessing whether someone is a potential threat to democracy, the assessor considers whether damage might be caused. Numerous experiments by, among others, Kahneman et al. [23], Cialdini [22], Taleb [24], and Ariely [21] show that, in such assessments, even professionals and specialists make both incidental and structural errors.

While the present article does not focus on measuring cognitive bias, we did keep in mind the favouring of the 'best person to do the job' over 'best practices' and noted that five respondents valued their own expertise in a way that tended towards overestimation (respondents two, seven, eight, nine and ten). This is a rather common bias, and is 
even more prevalent among experts than it is among lay-people [23]. Cognitive bias seems to be most present in municipalities where the coordinating security professional conducted threat assessments independently, without extensive discussions with other security partners from different backgrounds and fields. Most noticeable is the fact that assessments are then made based on information gathered from social partners (schools, youth workers, family support officers, and so forth) without any further discussion with professionals (such as the social worker) who are in contact with the youth being investigated. This raises doubts about whether all relevant pieces of the puzzle are sufficiently considered to objectively assess potential stages of radicalization, especially in cases dealing with vulnerable youth trying to find their identity.

Another type of judgment error, the so-called halo-effect (i.e., the assumption that the judgment of the police and justice department is always right), seemed to be present in three cases. This indicates an authority bias, whereby the assumptions of those in a position of authority are assumed to be correct and are, thus, insufficiently challenged (if at all) by the people around them [22]. Three security professionals explicitly mentioned the idea that police and justice officials are law enforcement agents and, thus, best know how to assess threats (respondents one, four, and twelve). Because of this authority bias, it appears that the security officer's relationship with the liaisons from the police and public prosecutor's office likely highly influences the outcome of the integral approach. This authority bias also raises the concern that municipal responsibility for decision-making is being displaced towards other partners in the local triangle.

In the other seven municipalities, there was less faith in the ability of oneself or one's network to assess threats. Instead, we heard about the doubts that existed regarding the practice of working within a multidisciplinary setting. Because of this, respondents from these municipalities were critical of themselves and of the assessment process that takes place within the 'weighing team' (respondents three, five, six, eleven, thirteen, fourteen, and fifteen). They wondered whether the risk assessment of ideologies was objective. Interestingly, it was particularly these seven respondents who indicated a significant need for reflection on the broad approach in general and the integral approach more specifically. This was illustrated by respondent five: 'An overview of different implementation practices would be very welcome, because that would allow us to compare.' This shows the need for transparency about current practice.

In the determination of whether a particular radicalization process is developing towards extremism, the person under investigation can provide determinative information. The answer to the question of what is going on can be found in conversations with the individual who is suspected of posing a threat and with the people in his/her environment. Seven interviewees noted this approach (respondents six, seven, eight, nine, ten, thirteen, and fourteen). These local security professionals felt it important to ascertain the stage of development that the individual being investigated was in. In the municipalities where these professionals worked, threat assessment thus included a conversation with the youth under investigation. This happened largely at the security professional's own initiative. At first sight, this seems to be a good approach; however, for this approach to succeed, the security professional must have sufficient knowledge of, and expertise in, conducting conversations about ideological and existential issues.

Furthermore, this personal approach risks influence from a very significant bias: confirmation bias, also known as the mother of all cognitive biases [49]. In the context 
of detecting signs of radicalization, confirmation bias would lead one to focus only on those physical or behavioural characteristics that match the potential risk profile (whether or not this profile is explicitly known), while ignoring anything that does not fit. This means the local security professional unintentionally accepts information that aligns with what he/she expects to find and rejects anything that does not fit - in other words, so-called profiling (confirming versus disconfirming evidence). The risk of such bias is increased due to the one-sided focus on religious (Islamic) extremism and Jihadism that so far has dominated the courses on detecting radicalization.

\section{Conclusion, discussion and recommendations}

Before reflecting on the outcome of this qualitative study on security professionals' early detection of (violent) extremism among youth at the local level, we must emphasise that the present study is not an evaluation of the effects caused by current public policy. It can, however be seen as a process evaluation. The analysis offers insight from policy to practice. Our objective is to map how local frontline professionals assess the risk of radicalization that leads to violent extremism, and determine the way in which these civil servants substantiate their decisions. We have done so by interviewing fifteen Dutch frontline professionals who are responsible for public order, security and safety at one of the prioritized municipalities in the Netherlands, and who receive special government funding for the implementation of CVE-policy. Thus, our conclusion is not a value judgment of the current practice in the Netherlands. Instead, our goal is to provide insight into the variation of real-life practices regarding pre-emptive screening, which can contribute to much-needed knowledge on preliminary counterterrorism practices.

Preventive early detection of extremism focuses primarily on ideas and deviant attitudes, and less so on concrete unlawful acts. This level of abstraction is accompanied by ambiguity in the assessment and initial weightings of potential threats. This study's most important conclusion is that the interviewed local civil servants responsible for public order, security and safety cannot (or at least do not) explicitly note the relevance of the intention to commit or incite violence in assessing whether someone poses a threat. We conclude that in the Netherlands, this is also due to the broad description of the assignment given to local security professionals by Justice and Security policy, which states: "be aware of people who pose a threat to democracy?'. This became even more apparent (in the interviews) when we directly asked the frontline safety professional on what basis they weigh whether someone poses a potential risk.

In all cases, no clear response was given. No one could concretely provide an actual description of the concept 'threat to democracy'. Respondents often indicated their inability to answer with a physical reaction, such as shrugging their shoulders, sighing or rolling their eyes. Almost all respondents indicated more or less explicitly that it comes down to an assessment made based on a gut feeling. Respondent fourteen gave a clear explanation: 'Of course, when no criminal acts have yet been committed, you can never be sure. You depend on your intuition, the idea that something isn't right.' Our results suggest that the interviewed local security professionals are not completely aware of the essence of the (legal) boundaries of the concept of early detection, which takes place during a pre-crime phase [50-52], let alone that they are aware of their role within an anticipatory-justice system. We believe this to be a missed opportunity for the effectiveness of counterterrorism policy. 
Furthermore, we found that counterterrorism policies in the municipalities, whose security professionals we interviewed, are insufficiently aware of the criminal law's focus on extremist language or extremist ideas that incite hate, discrimination and/or violence. The criminalisation of incitement to extremist violence is an exception to the freedom of expression. Thus, there is a legal distinction to be made between speech that forms a threat to democracy and speech that must not be subject to State interference. This legal boundary could provide the norm for threat assessment in the early detection process. However, the interviews revealed that local professionals responsible for security have difficulty in assessing abstract ideologies and/or ideas. They often give examples of youth exhibiting hostile language (referring to such things as a war with the West, or using statements such as 'down with the other', 'white power', 'we are stronger' or 'Islam will prevail'). Although such rhetoric is demonizing, accusing and can certainly cause division, the real question whether this speech is a regulated, and precise precursor to violent action? In other words do these young people always have the intention to use violence?

This perspective creates more awareness among first-line practitioners regarding the extent to which extreme ideas can be regarded as problematic, and which specific beliefs are problematic. What ideas should organizations and communities characterize as "radical"? And, in what situations is it only activism or non-violent extremism? Within science, extensive research is being conducted regarding the relationships between these phenomena, but there is no clear link (for an overview, see [53]). Terrorism experts, therefore, emphasize that it is not about derailed individuals - or radical persons, but about people who do not accept our legal order $[20,31,54,55]$. That is an important distinction in conducting risk assessments that use perceptions as a starting point; especially in an anticipatory phase of preventive screening [56]. These risk assessments may conceal future violence, however, this does not mean that they should be used across all cases of radicalism or extremism. Therefore, we argue that what should be measured is the preparedness to use extreme physical violence. This would allow one to better determine which stage of radicalization an individual is in.

To measure this, we suggest more attention must be paid to the youth's social interactions with his or her environment, instead of focusing on (a collection of) incidents like dropping out of school, fights, or unruly behaviour at school. It is insufficient to collect information about such incidents from diverse social institutions because this information does not give an objective impression of the actual individual under investigation. This view is in line with the four-part model that was developed by Borum [35] since the late 1990s for a BJA-funded program called SLATT (State and Local Anti-Terrorism Training). The model evolved out of his many SLATT trainings and was later used by the FBI. Borum's conclusion (from his empirical research) is that the answer to the question: what constitutes a "deviant ideology" is as follows: "From a social scientific viewpoint, it may be an unanswerable question. From a practical/ operational viewpoint, however, I think (in non-war contexts) ideologies that justify or mandate violent action -especially against civilians (to serve a broader "cause") is fair to use as a metric. In law enforcement, our job is not really to track how "extreme" a person's worldview or belief system might be. We are more concerned with how those beliefs and worldviews might facilitate or cause criminal - especially violent - action".

Thus, when assessing radicalization processes towards violent extremism, it is important to determine how the individual views him or herself in relation to the current 
social and political order. The feeling of not "being seen", "belonging", "mattering" is often the motivation for assuming a certain criminal- or violent-identity ([57], p. 795). Therefore, questions should be asked such as: does 'us' versus 'them' thinking occur? Why does he/she find certain ideas attractive? What are the personal social benefits? And, to what extent does the young person consider him/herself meaningful? This is in line with age-old socio-psychological theories (from crime prevention) among young people, where the question "am I meaningful to others?" is central $[58,59]$.

Young people who face such existential questions do not pose a direct threat to democracy or the safety of other citizens. Rather, these young people are more likely to be 'susceptible people' who may be influenced more through situational factors, not ideology itself. As stated by Corner, Bouhana and Gill [60], environmental and contextual factors are key to understanding the causes of extremism, alongside individual characteristics like susceptibility to moral change. Being susceptible means being exposed to settings that enable extremist socialization. It is the situation people are in, and not so much their beliefs, that poses a threat. So, drivers that contribute to the emergence of extremism risk need to be identified, irrespective of people. They're in the physical spaces, communities and social systems that surround their living environment. This scholarly view is also shared by Borum (2019): “The challenge is not police people's thoughts, but to observe cue's to a person's intentions or actions. Often that comes from dramatic changes within the individual, rather than the degree of extremism falling past an arbitrary 'cutoff' on a spectrum. There are plenty of people in the world who have extreme beliefs and many who would even justify violence in service of a social cause (see for example The Global Attitudes Project by PEW Research Centre) but the overwhelming majority of those people have not and will not act violently themselves."

Furthermore, the open interviews conducted with local frontline security professionals in this study indicate that most respondents' assessments of radicalization are not well substantiated. It appears that most municipalities do not sustainably invest in knowledge acquisition about early detection in a legal framework or regarding how to assess the intention or willingness to commit violence. This was also the basic conclusion reached in a recent review by Koehler and Fiebig [16], which states: "It finds that training courses are significantly disconnected from research. On the other hand, training in this field indicates that the academic literature is not well-grounded in the practical realities of delivering interventions." All civil servants who participated in this study had at one time or another followed a course or training, but most did not receive any follow-up, not to mention a follow-up focused on ideologies other than religious extremism or jihadism (possibly due to time pressure and lack of financial resources). However, developing expertise should be an ongoing process, especially when dealing with delicate matters such as the (in)justice and stigmatisation that can accompany wicked problems like deviant ideologies. In the end, what is a deviant ideology after all? Such sensitive matters in counter-terrorism practices require careful reflection regarding the practitioners behavior and decision-making processes, which has previously been stressed by [25] in their 'performativity' theory.

In conclusion, we recommend that early detection processes require local security professionals' awareness of, and reflection on what actually must be prevented within this pre-emptive approach. More clarity is needed on which risks and threats must be assessed and on the aim of this assessment. It must, for example, become clear whether the aim is to prevent all forms of radicalism, to identify individuals who pose a threat or to support those who seem at risk of 'dropping out' of society? In order to obtain clarity on these matters, it is 
of primary importance that frontline professionals become aware of the (legal) difference between radicalization in general and the willingness to commit extremist violence [19, 61]. After all, what violent extremism and terrorism have in common is their ideological motives for committing violence. The difference between the two is that in the former, only the willingness to commit violence is present, while in the latter, the actual act of violence has materialised [48].

This distinction allows us to use the term radicalization more precisely. What early detection policy at the local level is specifically trying to detect is radicalization towards extremist violence, not just any 'radical' individual who exhibits a deviant attitude. Therefore, the municipalities who direct the local approach, and thus, shoulder a large responsibility for implementing counterterrorism policy, should focus on detecting the intention to use violence, which is linked with the lack of respect for democratic core-values, such as freedom, equality and solidarity. Furthermore, because early detection operates within the intelligence and security sector, and because it can be seen as a type of anticipatory justice, it is imperative that approaches of the local CVE focus on the rule of law, democracy, human rights and normative concepts that include justice, tolerance and diversity. Only in this way can the community of values centred around democracy and the rule of law, and called for by the European Union Global Strategy [62], be realised. For there is no such thing as effectiveness at any cost - at least not in a democratic society where the rule of law is applied.

Open Access This article is licensed under a Creative Commons Attribution 4.0 International License, which permits use, sharing, adaptation, distribution and reproduction in any medium or format, as long as you give appropriate credit to the original author(s) and the source, provide a link to the Creative Commons licence, and indicate if changes were made. The images or other third party material in this article are included in the article's Creative Commons licence, unless indicated otherwise in a credit line to the material. If material is not included in the article's Creative Commons licence and your intended use is not permitted by statutory regulation or exceeds the permitted use, you will need to obtain permission directly from the copyright holder. To view a copy of this licence, visit http://creativecommons.org/licenses/by/4.0/.

\section{References}

1. Kundnani, A., \& Hayes, B. (2018). The globalisation of countering violent extremism policies. Undermining human rights, instrumentalising civil society. Amsterdam: Transnational Institute.

2. Romaniuk, P. (2015). Does CVE work? Lessons learned from the global effort to counter violent extremism. Goshen: Global Center on Cooperative Security.

3. Moors, J. A., \& Bervoets, E. J. A. (Eds.). (2013). Frontlijnwerkers in de veiligheidszorg: gevalstudies, patronen, analyse. Amsterdam: Boom Lemma uitgevers.

4. Castells, M. (1996). The information age: Economy, society and culture, vol. 1, the rise of the network society (revised ed.). Oxford: Blackwell.

5. Crawford, A. (2010). Regulating civility, governing security and policing (dis)order under conditions of uncertainty. In J. Blad, M. Hildebrandt, K. Rozemond, M. Schuilenburg, \& P. Van Calster (Eds.), Governing security under the rule of law (pp. 9-35). Den Haag: Eleven International Publishing.

6. De Graaf, B. A. (2011). 'Religion bites: religieuze orthodoxie op de nationale veiligheidsagenda', Tijdschrift voor Religie. Recht en Beleid, 2(2), 62-80.

7. Wittendorp, S., De Bont, R., Van Zuijdewijn, J. D. R., \& Bakker, E. (2017). Beleidsdomein aanpak jihadisme: een vergelijking tussen Nederland, België, Denemarken, Duitsland, Frankrijk, het VK en de VS (2010 to 2017). Leiden: Universiteit Leiden.

8. Crawford, A. (2009). Governing through anti-social behaviour: Regulatory challenges to criminal justice. The British Journal of Criminology, 49(6), 810-831. 
9. Eijkman, Q., \& Schuurman, B. (2011). Preventive counter-terrorism and non-discrimination in the European union: A call for systematic evaluation. In International Centre for Counter-Terrorism the Hague, working paper, 2. Den Haag: ICCT.

10. LaFree, G., \& Freilich, J. D. (2019). Government policies for counteracting violent extremism. Annual Review of Criminology, 2, 383-404.

11. Patel, F., \& Koushik, M. (2017). Countering violent extremism. Brennan Center for Justice, 2017, 9-10.

12. Van Ginkel, B. \& Entenmann, E. (Eds.) (2016). The Foreign Fighters Phenomenon in the European Union. Profiles, Threats \& Policies, The International Centre for Counter- Terrorism. The Hague 7(2)

13. De Graaf, B. A., \& Eijkman, Q. (2011). Terrorismebestrijding en securitisering. Justitiële verkenningen, 37(8), 33-52.

14. Ragazzi, F. (2017). Countering terrorism and radicalization: Securitising social policy? Critical Social Policy, 37(2), 163-179.

15. Aly, A., Balbi, A. M., \& Jacques, C. (2015). Rethinking countering violent extremism: Implementing the role of civil society. Journal of Policing, Intelligence and Counter Terrorism, 10(1), 3-13.

16. Koehler, D., \& Fiebig, V. (2019). Knowing what to do. Perspectives on Terrorism, 13(3), 44-62.

17. Mattsson, C. (2018). Caught between the urgent and the comprehensible: Professionals' understanding of violent extremism. Critical Studies on Terrorism, 11(1), 111-129.

18. Peddell, D., Eyre, M., McManus, M., \& Bonworth, J. (2016). Influences and vulnerabilities in radicalised lone-actor terrorists: UK practitioner perspectives. International Journal of Police Science \& Management, 18(2), 63-76.

19. Van de Weert, A., \& Eijkman, Q. A. (2018). Subjectivity in detection of radicalization and violent extremism: A youth worker's perspective. Behavioral Sciences of Terrorism and Political Aggression, 1-24.

20. McCauley, C. R., \& Moskalenko, S. (2016). Friction: How conflict radicalizes them and us. New York: Oxford University Press.

21. Ariely, D. (2008). Predictably irrational. New York: HarperCollins.

22. Cialdini, R. B. (2009). Influence: Science and practice (Vol. 4). Boston, MA: Pearson education.

23. Kahneman, D., Slovic, P., \& Tversky, A. (1982). Judgments under uncertainty. Heuristics and biases. Cambridge: Cambridge University Press.

24. Taleb, N. N. (2007). The black swan: The impact of the highly improbable (Vol. 2). New York: Random House.

25. De Graaf, B., \& De Graaff, B. (2010). Bringing politics back in: The introduction of the 'performative power'of counterterrorism. Critical Studies on Terrorism, 3(2), 261-275.

26. Harris-Hogan, S., Barrelle, K., \& Zammit, A. (2016). What is countering violent extremism? Exploring CVE policy and practice in Australia. Behavioral Sciences of Terrorism and Political Aggression, 8(1), 6-24.

27. Koehler, D. (2016). Understanding deradicalization: Methods, tools and programs for countering violent extremism. London/New York: Routledge.

28. Schuurman, B., \& Eijkman, Q. (2015). Indicators of terrorist intent and capability: Tools for threat assessment. Dynamics of Asymmetric Conflict, 8(3), 215-231.

29. Mastroe, C., \& Szmania, S. (2016). Surveying CVE metrics in prevention, disengagement and deradicalization programs. Report to the Office of University Programs, Science and Technology Directorate, Department of Homeland Security. College Park: START.

30. Husband, C., \& Alam, Y. (2011). Social cohesion and counter-terrorism: A policy contradiction? Bristol: Policy Press.

31. Kundnani, A. (2015). A decade lost: Rethinking radicalization and extremism. London: Claystone.

32. Neumann, P. R. (2013). The trouble with radicalization. International Affairs, 89(4), 873-893.

33. Ragazzi, F. (2016). Suspect community or suspect category? The impact of counter- terrorism as 'policed multiculturalism'. Journal of Ethnic and Migration Studies, 42(5), 724-741.

34. Schuilenburg, M. B. (2011). The securitization of society: On the rise of quasi-criminal law and selective exclusion. Social Justice, 38(1-2), 71-86.

35. Borum, R. (2003). Understanding the terrorist mind-set. FBI Law Enforcement Bulletin, Criminal Justice Periodicals, 72(7), 7.

36. Thomas, P. (2014). Divorced but still co-habiting? Britain's prevent/community cohesion policy tension. British Politics, 9(4), 472-493.

37. Borum, R. (2011). Radicalization into violent extremism I: A review of social science theories. Journal of Strategic Security, 4(4), 7-36.

38. Khalil, J. (2014). Radical beliefs and violent actions are not synonymous: How to place the key disjuncture between attitudes and behaviors at the heart of our research into political violence. Studies in Conflict \& Terrorism, 37(2), 198-211.

39. Kvale, S., \& Brinkmann, S. (2009). Interviews: Learning the craft of qualitative research (pp. 230-243). California: Sage. 
40. Rubin, H. J., \& Rubin, I. (2005). Qualitative interviewing: The art of hearing data (2nd ed.). California: Sage Publications.

41. King, N., \& Horrocks, C. (2010). An introduction to interview data analysis. Interviews in Qualitative Research, 142-174.

42. Durose, C. (2009). Front-line workers and 'local knowledge': Neighbourhood stories in contemporary UK local governance. Public Administration, 87(1), 35-49.

43. Durose, C. (2011). Revisiting Lipsky: Front-line work in UK local governance. Political studies, 59(4), 978-995.

44. Boeije, H. (2002). A purposeful approach to the constant comparative method in the analysis of qualitative interviews. Quality and Quantity, 36(4), 391-409.

45. Maynard-Moody, S. W., Musheno, M., \& Musheno, M. C. (2003). Cops, teachers, counselors: Stories from the front lines of public service. Ann Arbor: University of Michigan Press.

46. Geary, D. C. (2012). Folk knowledge and academic learning. In N. M. Seal (Ed.), Encyclopedia of the sciences of learning (pp. 1305-1310). New York: Springer.

47. Dzhekova, R., Stoynova, N., Kojouharov, A., Mancheva, M., Anagnostou, D., \& Tsenkov, E. (2016). Understanding radicalization. Review of the literature. Sofia: Center for the Study of Democracy.

48. Schmid, A. P. (2013). Radicalization, de-radicalization, counter-radicalization: A conceptual discussion and literature review. ICCT Research Paper, 97. Den Haag: International Centre for Counter-Terrorism (ICCT-The Hague).

49. Bertholet, A. G. E. M. (2016). Risico-intelligentie en risicovaardigheid van professionals in het veiligheidsdomein, Problemen bij het nemen van risico-beslissingen door denkfouten en beperkte gecijferdheid. Vakblad Voor Omgevingsveiligheid Risicobeleid en Risicocommunicatie, 7(22-23), 60-74.

50. Borum, R. (2014). Psychological vulnerabilities and propensities for involvement in violent extremism. Behavioral Sciences \& the Law, 32(3), 286-305.

51. Bhui, K., Warfa, N., \& Jones, E. (2014). Is violent radicalisation associated with poverty, migration, poor self-reported health and common mental disorders? PLoS One, 9(3), e90718.

52. Simi, P., \& Windisch, S. (2018). Why radicalization fails: Barriers to mass casualty terrorism. Terrorism and Political Violence, 1-20.

53. Schuurman, B., \& Taylor, M. (2018). Reconsidering radicalization: Fanaticism and the link between ideas and violence. Perspectives on Terrorism, 12(1), 3-22.

54. De Graaff, B. (2008). Hoe breed? Contraterrorisme-en radicaliseringsbeleid onder de loep. Monitor Racisme \& Extremisme; achtste rapportage, 125-140.

55. Overeem, P. (2017). Public service ethics and integrity: Some general lessons. In M. Kow-alski (Ed.), Ethics of counterterrorism (pp. 19-34). Amsterdam: Boom uitgevers.

56. Hirsch Ballin, M. F. H. (2012). Anticipative criminal investigation: Theory and counter-terrorism practice in the Netherlands and the United States of America (proefschrift). Den Haag: T.M.C. Asser Press.

57. Victoroff, J., Adelman, J. R., \& Matthews, M. (2012). Psychological factors associated with support for suicide bombing in the Muslim diaspora. Political Psychology, 33(6), 791-809.

58. Leary, M. R., \& Baumeister, R. F. (2000). The nature and function of self-esteem: Sociometer theory. In Advances in experimental social psychology (Vol. 32, pp. 1-62). San Diego: Academic Press.

59. Rogers, C. R. (1959). A theory of therapy, personality, and interpersonal relationships: As developed in the client-centered framework. In S. Koch (Ed.), Psychology: A study of a science (Vol. 3, pp. 184-256). New York: McGraw-Hill.

60. Corner, E., Bouhana, N., \& Gill, P. (2019). The multifinality of vulnerability indicators in lone-actor terrorism. Psychology, Crime \& Law, 25(2), 111-132.

61. Eijkman, Q., \& Roodnat, J. (2017). Beware of branding someone a terrorist: Local professionals on personspecific interventions to counter extremism. Journal for Deradicalization, Spring issue, 10, 175-202.

62. Biscop, S. (2016). The European security strategy: A global agenda for positive power. London: Routledge.

Publisher's note Springer Nature remains neutral with regard to jurisdictional claims in published maps and institutional affiliations.

\section{Affiliations}

\section{Annemarie van de Weert $^{1}$ • Quirine A.M. Eijkman ${ }^{1}$}

1 Centre for Social Innovation (KSI), Utrecht University of Applied Sciences, Padualaan 101 Postal Box, $3584 \mathrm{CH}$ Utrecht, The Netherlands 